\title{
Human Rights Organisations and the Egyptian Revolution
}

\author{
Mohamed Hussein El Naggar
}

\begin{abstract}
In much of the democratisation and development literature, human rights organisations were championed as whistle-blowers and advocates of justice. This article argues that human rights organisations were just as disconnected from the momentum of the force, building up prior to and at the wake of the revolution as other civil and political organisations and forces. An inhibitive political environment prohibiting political activism and an elitist internal culture meant that human rights organisations were far removed from the street. Yet they played an intermediary role in engaging with journalists, lawyers and activists as well as an indirect role in raising awareness of human rights violations, which facilitated the coalescing of a platform around the death of Khaled Said. The revolution however, has forced the human rights organisations to rethink their strategies of engagement and relationship with the masses. The extent to which this is forcing a paradigm shift remains to be seen.
\end{abstract}

\section{Introduction}

One of the principal sparks of the Egyptian revolution was the lack of respect for human rights, embodied by the killing of Khaled Said at the hands of police before the revolution. This raises questions about the extent of human rights organisations' contributions to the revolution. What role did they play in making it happen? To what extent did the strategies of the Egyptian human rights movement speak to the dynamics of social and political change? Another question concerns the generation gap within the human rights movement, a result of the lack of internal rotation of power. Are young people now taking their proper position within the movement, especially in light of the valorisation of the youth's role in the January 25th revolution?

There are two responses to the above question. The first is the simpler response: although many human rights activists and advocacy groups expected a greater political gridlock, more premeditated attacks on the press and media, the closure of newspapers, and the referral of journalists to trial, and even expected that in the end these conditions would lead to an explosion, no one expected a revolution of this size and the perseverance of young people to make it succeed. The goal of the human rights movement is not fundamentally revolutionary; rather it aspires and plans for incremental, gradual changes with the goal of promoting human rights principles and norms. ${ }^{1}$ Thus, the human rights movement pursues a reformist programme based on rectifying legislation and practice to become more humane and consistent with international human rights norms and basic liberties.

There has been an ongoing, longstanding debate, not only among rights advocates in Egypt, but all over the world, about the relationship between democracy as a political system and the acquisition of human rights and basic liberties more broadly. Numerous rights and liberties, such as freedom of opinion and expression and the right to representation and participation require a democratic system to flourish. Yet, the human rights movement in Egypt sought to create a political environment favourable to guarantees for human rights and basic liberties, regardless of the type of political system.

Even in times of heightened antagonism between rights groups and the state, these organisations never refused a government invitation to the table to talk. As such, rights groups are not assumed to engage in revolutionary activism, but largely in reforming the instruments, strategies and tools of 
the existing regime in order to promote human rights.

Yet, the question of the relationship between human rights organisations and the revolution is far more complex if approached from the perspective of human rights organisations' outreach, presence on the street, and their ability to mobilise. It is perhaps this ability, or lack of it, that prevents rights groups from engaging in any sort of mass activism, a situation that has been compounded by several factors, as discussed below.

\section{Legal and security restrictions}

Legal restrictions on all civic and political forums, from parties and labour syndicates to non-governmental organisations (NGOs) and human rights organisations, have served to isolate and insulate these forums from the street. The authorities used all means possible to limit any genuine role for these institutions, placing for example, severe restrictions on registration and licensing. The Egyptian Organization for Human Rights (EOHR), for example, operated 'under construction' for 15 years before finally receiving a licence as a civic association. Human rights organisations were severely hampered from registering as NGOs by the substantial flaws in the various NGO laws; from Law 32/1964 to Law 153/1999, which was declared unconstitutional, and finally to Law 84/2002. All of these laws put NGOs under the heavy hand of the law and the Ministry of Social Affairs, preventing them from genuine, effective action. These laws prompted organisations to find other legal frameworks under which to pursue their activities, such as non-profit civil companies subject to the civil code, as is the case with the Cairo Institute for Human Rights Studies (CIHRS), legal firms, like the Hisham Mubarak Law Center (HMLC) or research or academic firms; others were established as publication centres. This greatly weakened the social presence of these organisations, and in any case, these arrangements became illegal under Law 84/2002 on associations and private institutions.

Another significant drawback to these legal restrictions was that it fostered a tendency of rights groups to eschew the idea of membershipbased civic association. The leadership of these groups was well aware of the experience of the Tunisian Human Rights League: the Tunisian authorities intentionally planted its own personnel among the league's membership, later allowing them to take control of the general assembly.

Thus, rights organisations tended to establish either non-profit companies or private institutions regulated by the NGO law. Even those organisations that were registered as civic associations set strict conditions for membership or thought twice about accepting new members. The best example is the EOHR, the oldest rights group in Egypt after the Arab Organization for Human Rights: the EOHR has a membership of 3,000 while 7,000 prospective members are waiting for approval, some having applied for membership years ago. This wariness of security infiltration denied rights organisations the opportunity to attract supporters and members from all segments of society and, hence, cost them an effective entryway to society and social involvement. Most organisations have limited their circles to the political, social and cultural elite.

\section{Human rights organisations - the crisis of elitism}

From the late 1980 s, the human rights movement adopted the public relations mechanisms common to the global human rights movement, including the following:

1 Campaigns, which select a specific issue or phenomenon for intensive activities of various types over a specific time period with the goal of achieving objectives deemed realisable by the campaign organisers. One of the most prominent examples is the EOHR campaign in the early 1990 s to end torture, which managed to put the issue on the agenda of the People's Assembly after several MPs filed official questions about the issue.

2 Press engagements including urgent appeals that contain the institution's stance on a particular incident in order to inform the global public opinion.

3 Human rights reports that address a particular phenomenon such as torture and ill treatment in prisons or police stations.

4 Annual reports and activity reports.

5 Periodicals and journals (Hasan 2007).

Of all the public relations instruments that human rights organisations use to reach their audience, the publication is easiest but also the narrowest. The vast majority of rights groups issue numerous publications, most of them of 
good quality in terms of form and content, yet it is very difficult to gauge the impact of these various publications, but the general impression is that they rarely reach an audience thirsty for the knowledge they contain. More likely, the public, even the educated public, does not willingly read most of them, and rarely does any rights organisation, like any civil society institution or indeed government institution, receive a marked public response to these publications. Indeed, it is doubtful that they are closely read even by the narrow educated elite class, let alone the general public.

Certainly, many individuals read these publications motivated by different concerns, among them students, lawyers or others in the legal profession. Some members of the general public may read an educational pamphlet with some degree of interest or avidity when the pamphlet might help solve a personal problem. But the real response to publications by advocacy groups is extremely low compared to the effort and financial resources devoted to them (al Sayyid Sa'id 2004).

The lack of public enthusiasm and interest in these publications, despite the wealth of content they contain, can be attributed to two factors. First, the style and language used in them is of the dry academic type and not addressed at the general public or the person on the street.

Second, these publications are produced in full by projects funded by various donors. This means that the rights organisations cannot sell them, but only distribute them free by mail or in person. This deprives these publications of a fundamental part of their value as a means of communication with society, particularly since rights groups share largely similar mailing lists. One person may receive dozens of publications, which deters him from reading them unless a topic grabs him. In turn, despite their importance, the reach of publications is limited to a closed circle of the educated elite in Egypt.

The same observations apply to intellectual forums and cultural seminars organised by rights groups, which are largely limited to a select group of attendees invited by e-mail, regular mail or hand-delivered invitation. Normally, these events do not have a large audience, only a few dozen in the best of cases (although events focused on political Islam or Palestine may be well attended). These organisations do not normally organise mass activities, for two reasons: first, security harassment, which deters these sorts of activities and second, doubts that the issues are of interest to a wider audience.

The HMLC pursued another tack by embracing several popular, protest and labour movements, which gave the centre a presence among these movements. The centre also volunteered to defend any person detained or arrested in connection with labour or popular protests, which boosted the centre's credibility in these circles. ${ }^{2}$

Legal aid and the receipt of complaints is the most popular and socially effective tactic, as rights organisations' relationship with society is partly based on common interests. Thus, the groups that document, monitor and collect complaints are the most connected with society. The EOHR and the HMLC receive the most complaints, which have increased enormously since the revolution.

With the spread of social media networks before and after the revolution, most of these organisations also established pages on Facebook and Twitter to connect with the public, yet, the number of participants in these pages is still quite small compared to their peers in other countries such as Palestine.

\section{Crisis of trust between rights organisations and society}

Although the state's media apparatus, comprised largely of newspapers and television channels, failed abysmally to convince the public of its policies or even of its credibility, when it comes to human rights organisations, the state succeeded in building a firm barrier between these groups and the public. The state media apparatus successfully impugned the reputation of these groups for being recipients of foreign funding by accusing them of implementing foreign, Western agendas that target the state's sovereign decision-making authority. The state laid severe legal conditions on their ability to access foreign funding, evidenced in an order of the Military Governor, which required permission from the Supreme Council of the Armed Forces (SCAF) to receive such funds. This legal restriction has brought NGOs, and especially groups working in human rights, to a dead end and increased their dependence on non-approved foreign funding. 
SCAF then attempted to pressure foreign donors themselves, while also launching vicious campaigns against groups that received such funding, taking legal action against some. These smear campaigns have generally been met with positive responses among several sectors of society; however, they tend to be elite corps within civil society rather than the public more generally.

Perhaps a new tendency on the part of several organisations to hold their training sessions and seminars in five-star hotels and tourist resorts has only stoked suspicions about foreign funding and therefore increased these organisations' isolation from the broader society.

\section{Political stagnation and the generational crisis within rights organisations}

As most rights organisations have chosen to take the form of companies, they have become personalised organisations, known more for the name of their founder than for the association's name or specialisation. The rotation of power within these organisations is extremely limited, which has fostered political stagnation. Advocacy groups are divided into two major parts. The first comprises the founders, who have become public figures invited to public and private, local and foreign activities and who are prominent on television screens and the pages of private newspapers, both independent and opposition. The second part comprises the staff of these organisations, who shoulder the brunt of the work for the organisations' activities and projects, although most of them do not share the limelight. Usually, the average salary of the staff pales in comparison to the relatively large salaries of the director or founder of the organisation in his capacity as project director or director of most or all of the institution's projects.

Any political conflict within the organisation or attempts by the second generation to advance usually takes one of two routes: either the subordinate accepts the dictates and convictions of the director or founder, or s/he leaves the organisation and establishes an independent group. This choice has become a refuge for numerous activists, who have spontaneously moved from the ranks of unknown staff to the class of founder and director, especially given the haphazardness with which some donors parcel out large grants, without due consideration for the history, experience and ability of the organisation, not only to administer and implement its activities, but to manage the grant funds themselves. Indeed, these organisations have attracted many figures who have no connection to the human rights movement.

The primary factor in the success of these organisations is grant-proposal writing and the skilful management of relations with donors. Thus, human rights groups have seen waves of new entrants, most prominently before the parliamentary elections of 2005, when several new organisations emerged, many of them involved in election monitoring and training projects. The most recent wave came after the revolution, when the second and even third generation of young people who previously worked with these organisations established their own groups. Others were attracted to the field by the announcement of increased funding opportunities for political awareness-raising. This state of affairs has created a distorted human rights community, where continuity and survival is not grounded in the society for which they ostensibly work and where social or popular acceptance or social incorporation is not a factor for continuity. Many of these organisations were founded far from the street and society, and their ability to obtain funding is the principal determinant of their continuity and success.

These reasons, in whole or in part, have deprived human rights groups of an active street presence and their ability to act as mass-based organisations that engage in political and social activism, capable of influencing the masses and the larger society.

\subsection{Elitist activism vs street activism}

One of the major contradictions we have witnessed in Egyptian public life in recent years is the great disconnect between all civil and political organisations and the wave of systematic yet spontaneous protests that erupted. These protests exposed that neither the political parties nor civil society organisations could claim real leadership of the people - and this became evident in the first days of the revolution. Despite the fact that these protests could have provided fertile ground for civil society organisations or political parties to form a populist constituency, they never really made a genuine effort to engage with the actors or the events. The involvement of human rights organisations was limited to issuing 
a rights statement or sending an investigations commission at the most. Human rights organisations never sought to establish coalitions with labour or syndicate movements, and the notion of collective action remained poor; they worked as separate islands suffering from overlap in their activities and lack of outreach.

No doubt, rights organisations were not at the centre of events when the revolution erupted. Yet to be fair, rights groups did create awareness within society of human rights issues and make them into matters of public opinion. They have defined the minimum threshold of rights. Indeed, many media and cultural figures attribute the January revolution to two primary issues. The first is the case of Khaled Said, which is at root a human rights issue, and the case was made public thanks to rights organisations, which also publicised several other issues that would have been covered up in the past, whether due to fear of security or in the context of a deal with the security apparatus. Humiliating treatment by the security forces was no longer acceptable to many citizens who were more informed and understood the basic threshold of their rights. Claims based on rights followed by litigation before the courts or complaints with human rights organisations became a familiar threat used by victims in police stations and detention facilities. The second is the case of wide-scale rigging that took place in the 2010 parliamentary elections and which human rights organisations played a critical role in documenting and exposing.

The nature of human rights abuses and basic liberties were clearly demarcated, and some Egyptian films began addressing these themes, seen particularly in the films of late director 'Atif al-Tayyib, such as al-Bari' ('The Innocent') and Didd al-Hukuma ('Against the Government'). These generated a cumulative, collective awareness of human rights concepts, standards and values, and human rights issues became public opinion issues.

If rights groups were not successful in reaching the Egyptian street, they did reach intermediary groups, most importantly a distinguished group of lawyers, journalists and researchers, who acted as conduits between these groups and society. These intermediaries, who had benefited from various training programmes, used human rights terms and concepts in defence arguments before the courts and made them a principal standard by which to assess government policies in the media. In addition, the new generation of web users and bloggers connected to social media sites such as Facebook and Twitter were wellversed in human rights, and they were extremely active in documenting human rights abuses, particularly on their personal web-pages or blogs. Blogger Wael Abbas was the first to post a video of torture in a police station on his blog, al-Wa' $i$ al-Masri.

Although for the reasons explained above, rights groups are accused of elitism and are largely limited to a small circle of highly educated, conscious people, the first sparks of the revolution came from precisely this social class, which comprised members of social network sites, bloggers and students at Egyptian and foreign universities, who are one of the prime target groups for rights organisations.

Thus, although rights groups were unable to play a leading role in the revolution, given their very limited street capacities, over many years of struggle and work, they did contribute, among many other actors, in cultivating a social consciousness of rights and liberties, which in turn fostered a cognitive dissonance between rights and liberties as they should exist and the painful reality. This conflict ultimately exploded in the form of the Egyptian revolution. Thus, one can consider rights groups as playing a role in relation to the revolution, but only indirectly.

Many issues, particularly the issue of torture, became a matter of public concern, and the unacceptability of torture in prisons and police stations was built into the social consciousness. Torture then became a reason to demonstrate or protest. Indeed, in some villages and communities, torture prompted the storming of police stations and the targeting of police personnel. This is in addition to socioeconomic issues, such as a minimum wage, which also became a primary demand of the revolution.

The most important role of rights organisations in the revolution was their documentation of human rights violations during the revolution, their appeals to international human rights organisations and the focus on a rights-based perspective in the media coverage of events. 


\section{Eruption of the revolution and the role of rights organisations}

Rights organisations engaged with the revolution in three major spheres. First, they formed factfinding commissions and anti-corruption committees, a tack pursued by the EOHR. On 3 February, several representatives of civil society groups and human rights activities met in the offices of the EOHR to discuss the current situation and consider appropriate means to support the demonstrators and their demands, and hold to account all those responsible for the abuses since the January 25th demonstrations. These individuals and groups then formed the Egyptian Fact-Finding and Anti-Corruption Commission. $^{3}$

The fact-finding commission assumed the task of observing and documenting these abuses, and identifying the persons responsible, so that all measures could be taken to hold them accountable for their crimes. The commission also contacted the International Red Cross to arrange for food and medicine for the besieged demonstrators.

In addition to the commission's actions, the EOHR documented some 1,000 casualties of the revolution, including the injured and the dead. But these efforts were not published in a report or even online; rather the EOHR issued a press statement carrying only five or six testimonies as an example.

In reaction, civilians began being referred to military courts (up to 12,000 as of August 2011) on various charges and most were convicted - a flagrant violation of the right to a fair trial and, insofar as military courts are exceptional courts for the prosecution of military personnel, inconsistent with international human rights charters. The EOHR issued a report entitled 'Military Courts: The Infringement of Guarantees for a Fair Trial', to document cases of civilians referred to military courts after the revolution.

Moreover, human rights organisations in conjunction with the CIHRS issued a document setting out a number of principles designed to guarantee that the Egyptian constitution will be based on the values of the January 25th revolution and its most prominent slogan: 'Freedom, Dignity, Social Justice'. The principles set out in six detailed articles are based on the sovereignty of the people as the source of all authority, and the document was signed by more than 25 rights organisations.

The document of these principles was called a 'papyrus', in appreciation of ancient Egyptian civilisation and the great cultural heritage of cultural, social, ethnic and religious diversity that has shaped Egyptians' character and identity. The productive interplay of Pharaonic, Nubian, Coptic, Arabic and Islamic civilisations constitutes a source of pride and respect for all Egyptians, the origin of Egyptian particularity, and the backbone of their sacred national union. Based on a recognition of this diversity and pluralism, the papyrus advocates the need for the constitution to recognise numerous sources of legislation as a supra-constitutional principle that reflects Egyptians' religious, confessional, ethnic and cultural diversity. Egyptian identity cannot be reduced to one dimension without destroying Egyptians' national union.

The papyrus refrains from elaborating in detail the rights to be enshrined in the constitution and legislation, choosing instead to emphasise that international human rights conventions should constitute the supreme reference point for the elaboration of these rights. The papyrus proposed to immunise these rights against any infringement based on ostensible 'democratic' pretexts that claim majority backing through the formation of a Constitutional Council to oversee this task, composed of the heads of the high courts and chaired by the president of the Supreme Judicial Council. Nor did the papyrus propose a particular system of governance (parliamentary, presidential or mixed), but rather leaves this to the constitution. It simply advanced a set of supreme constitutional provisions that must be respected in any democratic system, regardless of the specific mode of governance adopted by the constitution.

Another major arena of human rights activism, represented by the $\mathrm{HMLC}^{4}$ and the ECESR (Egyptian Center for Economic and Social Rights), might be called support for the revolution and the revolutionaries. From the first day of the revolution, the HMLC played a vital role, forming part of the field hospital and making the centre a locus of consultation, action and security plans, and a meeting point for popular and labour leaders. As a result, on 3 February, members of the military police surrounded 1 Tawfiqiya Market 
Street, the building where the HMLC offices are located and also home to the ECESR. Some 70 thugs surrounded the building as well, chanting 'traitors and collaborators', after which the military police entered and searched the offices of both organisations. At the time, the HMLC was being used as an operations room for the Front to Defend Egyptian Demonstrators, which included both activists with the centre as well as several volunteer lawyers and researchers. Many activists with the centre were in Tahrir Square helping to document violations by the Egyptian authorities. Several staff members of both the HMLC and the ECESR were arrested, including Ahmad Sayf alIslam Hamad, a lawyer with the HMLC; lawyer Mustafa al-Hasan Taha; Muhsin Bashir, an attorney with the HMLC; Muna al-Misri, a researcher with the HMLC; Fatima 'Ibada; Sa'id Hadadi, a researcher with Amnesty International; and Daniel Williams, a researcher with Human Rights Watch.

The HMLG has taken on several cases. On 14 March 2011, it sued for the dissolution of the State Security Investigations apparatus (SSI) and the conversion of its offices into museums under the Ministry of Culture in memory of the revolution. It also adopted the cause of the political activists in solidarity with events at the Two Saints Church (see Ali, this IDS Bulletin), as well as issuing numerous legal studies on constitutional amendments and military trials.

These spheres of activism described above have represented the primary strategic focuses for rights organisations since the eruption of the revolution. Yet, these activities and those of many other organisations have reflected a fundamental confusion between politics and advocacy. The reference point for post-revolutionary action on the part of several organisations was political rather than legal or rights based. In addition, at the beginning of the revolution, several organisations announced they would form a political party, although they later retracted this. Rights centres hosting protest groups and meetings, despite the nobility of the idea, also walk the line between politics and advocacy.

Since the US administration announced that it would give $\$ 40$ million in support of civil society organisations, a new crisis of foreign funding looms on the horizon, particularly for rights groups. It is clear that Egyptian society is deeply ambivalent in principle about the idea of foreign funding, despite the noble objectives that will be advanced by the funds. The problem is compounded by a lack of transparency in the budgets of advocacy groups and the fact that the vast majority do not declare their budgets or their sources of funding. This has put rights groups back at square one after the gains made during the revolution.

\section{Conclusion: the future of rights groups post revolution}

The January 25th revolution exposed the crisis of disconnect between the rights groups and the street. These organisations had long been constrained by legal and security interference, which isolated them and limited their activism and outreach. Many organisations refused to register as member-based associations, and even those that did, set strict conditions for membership, rejecting or freezing many membership applications. Except in rare cases, they were prisoners in their Cairo offices. Thus, for rights groups to play a pioneering role in lobbying for progressive social and political change in Egypt, they must take action on the following fronts:

1 Resolve the problem of foreign funding by working on several levels. First, they must initiate a transparent, open dialogue with political and social forces on foreign funding and available alternatives. Second, they must be transparent about foreign funding by declaring all the grants they receive and releasing their annual budgets to the official press. Third, they must look for alternatives to foreign funding by activating membership, collecting membership dues and approaching businessmen for grants following the relaxation of security's grip over these groups. Fourth, they must promote and disseminate a culture of volunteerism in society in order to minimize the cost of projects and programmes they sponsor. They will be helped in this by the fact that the revolution has created a huge momentum for volunteerism and participation, particularly among youth. Thus, attracting volunteers is no longer as difficult as it was in the past. The difficulty now is administering a clear, defined programme to manage volunteers and get the most out of them without losing them or their enthusiasm. Perhaps the formation of a volunteer network could act as the nucleus to increase the popular reach of these groups. 


\section{Adopt a strategy for popular expansion and outreach} through mass activities based on raising awareness of human rights values and concepts and familiarising citizens with their rights and duties. These activities should extend outside the capital to peripheral cities, and organisations should engage with citizens' demands and defend their rights through work units in the field and legal aid departments, which may rely on a group of volunteer lawyers trained in the application of international human rights instruments in local courts. The attorneys could be compensated with thankyou letters or their names published in the association's publications, or they could be honoured in ceremonies attended by a select political and social elite or given nominal remuneration. These types of actions will help integrate groups into society through common interests and by nurturing a strong sense among citizens of the importance of human rights groups and their centrality to society, so that society itself becomes the first line of defence against any blatant security interventions or infringement on their presence or activities. The primary source of power of the EOHR remains the fact that it receives complaints and maintains a legal aid unit. It receives thousands of complaints every year, thus establishing a broad community of beneficiaries.

3 Creating and strengthening cross-cutting collective work: rights organisations must not only speak among themselves but extend their outreach to other civil society actors such as:

- development associations who have a broad popular base;

- professional syndicates, with their substantial political weight in society;

- youth centres, given that young people currently act as the engine of events and protests in Egypt.

\section{Notes}

1 Interview with Hafiz Abu Sa'da, SecretaryGeneral of the Egyptian Organization for Human Rights, for this article (2011).

2 Ahmad Sayf al-Islam Hamad, Director of HMLC, in an interview for this article (2011).

3 First statement of the Fact-Finding and AntiCorruption Commission; 4 February 2011.

4 HMLG is an Egyptian human rights advocacy centre that focuses on litigation, campaigns
Such coordination could pull the rights movement out of its isolation and open it to all classes and social groups. For this strategy to succeed, organisations must be fully convinced of the importance of participation, they must function like peers and equals and not assume that they can instrumentalise the relationship with other organisations for their own purposes. Moreover, the stances taken by civil society will be stronger if they issue from a larger, more diverse, popular base.

4 Bring in the youth: the January 25th revolution revealed the latent energy of Egyptian youth, which can no longer be ignored. Rights organisations must adopt a strategy to involve young people in advocacy work and rely on them directly as messengers of human rights, ideas and values. This cannot be done without opening institutional channels within organisations to allow young people to ascend to senior positions.

5 Take note of the mix of advocacy, partisanship and politics: many leaders and staff at human rights organisations have political commitments and loyalties. They will thus face a challenge in the coming phase, regarding the stance of rights groups on human rights violations. Many political forces fear that religious movements will dominate Egyptian politics, which has led some of them to turn a blind eye to human rights abuses by the military, focusing instead on the actions and stances of Islamist forces, especially since some opposition figures have entered the government and these figures are colleagues of media workers and civil society leaders. Rights groups must thus take care to draw a line between themselves and the state, in whatever guise and whoever represents it, so that they are able to preserve their critical stance on human rights violations regardless of their source..$^{5}$

and legal research inside Egypt. Established in 1999 as a law firm subject to the Egyptian bar law, the centre has branches in Cairo and Aswan. As many of the staff tend to the left of the political spectrum, the centre is known for embracing popular and protest movements, particularly labour protests, for the legal aid given to prisoners and detainees of conscience.

5 Ahmad Sayf al-Islam Hamad, Director of HMLC, in an interview for this article (2011). 


\section{References}

al-Sayyid Sa'id, Muhammad (2004) Human Rights Organizations and Reaching the Egyptian Citizen on the Street: Is Anyone Listening? Elitism and Popular Orientation of Human Rights Movements [in Arabic], paper presented at the conference to mark the 20th anniversary of the emergence of human rights organisations, Human Rights Center for the Assistance of Prisoners

Hasan, 'Isam al-Din (2007) The Media Performance of Human Rights Organizations: Rules and Obstacles [in Arabic], Cairo 